\title{
Arcuate Nucleus Transcriptome Profiling Identifies Ankyrin Repeat and Suppressor of Cytokine Signalling Box-Containing Protein 4 as a Gene Regulated by Fasting in Central Nervous System Feeding Circuits
}

\author{
J.-Y. Li,* R. Kuick,† R. C. Thompson, ‡ D. E. Misek,† Y.-M. Lai,* Y.-Q. Liu,† B.-X. Chai,* S. M. Hanash†§ and I. Gantz* \\ Departments of *Surgery, †Pediatrics, ¥Psychiatry and §Communicable Diseases, University of Michigan, Ann Arbor, MI, USA.
}

Key words: obesity, pro-opiomelanocortin, neuropeptide $\mathrm{Y}$, hypothalamus, posterior hypothalamus, amygdala.

\begin{abstract}
The arcuate nucleus of the hypothalamus is a primary site for sensing blood borne nutrients and hormonal messengers that reflect caloric status. To identify novel energy homeostatic genes, we examined RNA extracts from the microdissected arcuate nucleus of fed and 48-h fasted rats using oligonucleotide microarrays. The relative abundance of 118 mRNA transcripts was increased and 203 mRNA transcripts was decreased during fasting. One of the down-regulated mRNAs was ankyrin-repeat and suppressor of cytokine signalling box-containing protein 4 (Asb-4). The predicted structure of Asb-4 protein suggested that it might encode an intracellular regulatory protein, and therefore its mRNA expression was investigated further. Reverse transcription quantitative polymerase chain reaction was used to validate down-regulation of Asb-4 mRNA in the arcuate nucleus of the fasted Sprague-Dawley rat (relative expression of Asb-4 mRNA: fed $=4.66 \pm 0.26$; fasted $=3.96 \pm 0.23 ; n=4, P<0.01$ ). Down-regulation was also demonstrated in the obese fa/fa Zucker rat, another model of energy disequilibrium (relative expression of Asb-4 mRNA: lean Zucker $=3.91 \pm 0.32 ; \mathrm{fa} / \mathrm{fa}=2.93 \pm 0.26 ; \mathrm{n}=5, \mathrm{P}<0.001$ ). In situ hybridisation shows that Asb-4 mRNA is expressed in brain areas linked to energy homeostasis, including the arcuate nucleus, paraventricular nucleus, dorsomedial nucleus, lateral hypothalamus and posterodorsal medial amygdaloid area. Double in situ hybridisation revealed that Asb-4 mRNA colocalises with key energy homeostatic neurones. In the fed state, Asb-4 mRNA is expressed by $95.6 \%$ of pro-opiomelanocortin (POMC) neurones and $46.4 \%$ of neuropeptide $\mathrm{Y}$ (NPY) neurones. By contrast, in the fasted state, the percentage of POMC neurones expressing Asb-4 mRNA drops to $73.2 \%(\mathrm{P}<0.001)$. Moreover, the density of Asb-4 mRNA per fasted POMC neurone is markedly decreased. Conversely, expression of Asb-4 mRNA by NPY neurones in the fasted state is modestly increased to $52.7 \%(P<0.05)$. Based on its differential expression, neuroanatomical distribution and colocalisation, we hypothesise that Asb-4 is a gene involved in energy homeostasis.
\end{abstract}

Tremendous advances have been made in identifying the molecular signals and neuroanatomical pathways that regulate body weight. Research has established that leptin, insulin, ghrelin, peptide $\mathrm{YY}_{3-36}$ and cholecystokinin, and nutrients such as glucose and fatty acids, are key peripheral messengers, which communicate energy status to central nervous system (CNS) centres involved in energy homeostasis (1-3). In addition, there is evidence that two preproglucagon derivatives, glucagon-like peptide 1 (4-6) and oxyntomodulin $(7,8)$, and pancreatic polypeptide (9-12) are physiologically relevant peripheral nutrient messengers. A number of other peptides and metabolic products may also partake in this process (13). Notably, with the exception of ghrelin, which is orexigenic (appetite-stimulating), these mediators are anorexigenic (satiety-inducing) and provide negative feedback.

Insulin, leptin and peptide $\mathrm{YY}_{3-36}$, and presumably glucagon-like peptide 1, oxymodulin and pancreatic polypeptide, enter the CNS across permeable areas in the blood-brain barrier and reach target neurones in the arcuate nucleus of the hypothalamus and dorsal vagal complex of the brainstem (1, 14). Cholecystokinin and ghrelin transmit their messages through vagal afferents (15).

Inasmuch as arcuate nucleus and dorsal vagal complex neurones are the first CNS neurones to receive peripheral 
nutrient signals, they can be regarded as 'first order' sensory neurones in the homeostatic process $(1,14)$. After sensing and integrating peripheral and central signals, these 'first order' neurones communicate with 'second order' effector neurones. Afferent projections to the arcuate nucleus from numerous brain regions undoubtedly contribute to this process $(16,17)$.

The cytoarchitecture of the arcuate nucleus is consonant with its first line status in energy homeostasis. Over the past decade, physiological (18-20), neuroanatomical (21-31) and gene targeting studies (32-34) have identified two physiologically opposing populations of arcuate nucleus neurones, which are crucial to energy homeostasis. The first population is located predominantly in the ventromedial arcuate nucleus and coexpress the orexigenic neuropeptides neuropeptide $\mathrm{Y}$ (NPY) and agouti-related protein (AGRP). The second population is located predominantly in the ventrolateral arcuate nucleus and coexpress anorexigenic neuropeptides derived from the pro-opiomelanocortin (POMC) prohormone [e.g. $\alpha$ - and $\gamma$-melanocyte stimulating hormones (MSH)] and the cocaine- and amphetamine-regulated transcript (CART). This is a remarkable functional organisation from the perspective that AGRP is a competitive antagonist of $\alpha$ - and $\gamma$-MSH at two key brain receptors involved in energy balance, namely the melanocortin-3 and -4 receptors (33, 35-39).

Despite this wealth of knowledge about arcuate nucleus physiology, it is likely that key regulatory genes involved in energy homeostasis remain unidentified. To identify such genes, we performed gene chip array studies on the microdissected arcuate nucleus. In the present study, we provide a list of candidate arcuate nucleus energy homeostatic genes whose mRNAs are regulated by fasting, and discuss in detail a gene previously annotated according to its two structural domains, ankyrin-repeat and suppressor of cytokine signalling box-containing protein $4(A s b-4)$. Because these predicted structural motifs suggested to us that $A s b-4$ might encode an intracellular protein that binds and regulates the function of other energy homeostatic proteins, the gene was selected for more detailed examination.

\section{Materials and methods}

\section{Animals and experimental protocol}

Seven-week-old male Sprague-Dawley rats (Harlan Laboratories, Madison, WI, USA) (weighing 280-300 g) were used for microarray studies. Rats within a treatment group were housed in the same cage under conditions that are in accordance with the University of Michigan Unit of Laboratory Animal Medicine guidelines. Animals were maintained at $22 \pm 2{ }^{\circ} \mathrm{C}$ in a room under a $12: 12 \mathrm{~h}$ light/dark cycle. The University Committee on Use and Care of Animals approved all animal experiments. The experiment was repeated five times. For each of the five experiments, four rats were included in the fed group and four rats in the fasted group. Therefore, a total of 20 fed and 20 fasted rats were eventually used to obtain five separate paired RNA samples. Animals in the fed group were allowed free access to regular rat chow and water throughout the 48 -h time course of the experiments. Animals in fasted group were food deprived for the 48-h time course of the experiments but were allowed free access to water. Experiments were initiated at $10.00 \mathrm{~h}$ and all dissections were performed between $10.00 \mathrm{~h}$ and $11.00 \mathrm{~h}$. At the end of the 48-h period, animals were sequentially euthanised by decapitation and their brains rapidly dissected. Brains were imbedded in powderised dry ice. A $1 \mathrm{~mm}$ acrylic coronal brain matrix (Braintree Scientific, Inc., Kingston, MA, USA) was used for sectioning. Rostrally, a coronal cut was made immediately posterior to the optic chiasm and a second coronal cut was made $2 \mathrm{~mm}$ caudal to the first. The 2-mm block of brain was used for microdissection. Brain sections were placed on dry ice and under $4 \times$ magnification a Stoelting 0.77 $\mathrm{mm}$ brain punch was used to obtain arcuate nucleus tissue. Punches were made bilaterally adjacent to the third ventricle above the median eminence. Because the punch is circular, small portions of the arcuate nucleus could have been excluded and small amounts of tissue from adjacent nuclei included. Tissue from each group was pooled for RNA extraction using a Dounce homogeniser and TRIzol Reagent (Life Technologies, Rockville, MD, USA). After the $75 \%$ ethanol wash step in the TRIzol extraction procedure, RNA from pooled arcuate nucleus was dissolved in water. An additional cleanup step was then performed using the Qiagen RNeasy Mini Kit per manufacturers instructions (Qiagen, Valencia, CA, USA).

$5 \mu \mathrm{g}$ of total RNA was converted into double-stranded cDNA using a Superscript Choice System for cDNA synthesis (Invitrogen, Carlsbad, CA, USA) with an oligo (dT) 24 primer containing a T7 RNA polymerase promoter at its 3' end (Genset, La Jolla, CA, USA). Following second strand synthesis, labelled cRNA was generated from the cDNA sample by an in vitro transcription reaction supplemented with biotin-11-CTP and biotin-16-UTP (BioArray High Yield RNA Transcript Labeling Kit, Enzo, Farmingdale, NY, USA). The labelled cRNA was purified using a Qiagen RNeasy spin column (Qiagen). $15 \mu \mathrm{g}$ of each cRNA was fragmented at $94{ }^{\circ} \mathrm{C}$ for $35 \mathrm{~min}$ in fragmentation buffer $(40 \mathrm{mM}$ Tris-acetate $(\mathrm{pH} 8.1), 100 \mathrm{~mm}$ potassium acetate, $30 \mathrm{~mm}$ magnesium acetate) and then used to prepare $300 \mu \mathrm{l}$ of hybridisation cocktail $[100 \mathrm{~mm}$ 2-(morpholino)ethanesulphonic acid, $1 \mathrm{M}$ $\mathrm{NaCl}, 20 \mathrm{~mm}$ EDTA, $0.01 \%$ Tween 20] containing $0.1 \mathrm{mg} / \mathrm{ml}$ of herring sperm DNA, $500 \mu \mathrm{g} / \mathrm{ml}$ acetylated bovine serum albumin and a mixture of control cRNAs (BioB, BioC, BioD and Cre) for comparison of hybridisation efficiency between arrays and for relative quantification of measured transcript levels. Before hybridisation, the cocktails were heated to $94{ }^{\circ} \mathrm{C}$ for $5 \mathrm{~min}$, equilibrated at $45^{\circ} \mathrm{C}$ for $5 \mathrm{~min}$, then clarified by centrifugation $(16000 \mathrm{~g})$ at room temperature for $5 \mathrm{~min}$. Aliquots of each sample (10 $\mu \mathrm{g}$ of fragmented cRNA in $200 \mu$ l of hybridisation cocktail) were hybridised to the Affymetrix Rat Expression Set 230 A and B arrays (Affymetrix, Santa Clara, CA, USA) at $45^{\circ} \mathrm{C}$ for $16 \mathrm{~h}$ in a rotisserie oven set at 60 r.p.m. The arrays were then washed with nonstringent wash buffer $(6 \times$ SSPE $)$ at $25^{\circ} \mathrm{C}$, followed by a stringent wash buffer [100 mM 2-(morpholino)ethanesulphonic acid (pH 6.7), $0.1 \mathrm{M} \mathrm{NaCl}, 0.01 \%$ Tween 20] at $50{ }^{\circ} \mathrm{C}$, stained with streptavidin-phycoerythrin (Molecular Probes, Eugene, OR, USA), washed again with $6 \times$ SSPE, stained with biotinylated antistreptavidin $\mathrm{IgG}$, followed by a second staining with streptavidin-phycoerythrin, and a third washing with $6 \times$ SSPE. Rat $230 \mathrm{~A}$ and $230 \mathrm{~B}$ arrays have 31042 probe-sets representing 28757 genes and 30248 transcripts.

\section{Microarray analysis}

Microarrays were scanned and probe intensities obtained with software from Affymetrix (Microarray Suite 5.0). Default analysis to obtain probe-set intensities as well as present calls were obtained from the Affymetrix software. We also used our own publicly available software (http://www.dot.ped. med.umich.edu:2000/pub/arc/index.html) to obtain probe-set intensities and normalise them, as described below. Rat expression set $230 \mathrm{~A}$ and $230 \mathrm{~B}$ arrays were processed separately, using the first fed sample as the standard in each case. Each probe-set on the arrays typically consists of 1125 -base oligonucleotides complementary to a specific cDNA, which are called perfect match (PM) features, and 11 mismatch (MM) probes that are identical to the PM probes, except that the central base has been altered. Probe-pairs with PMMM $<-100$ on the standard were removed from the analysis. One-sided signed-rank tests of PM-MM > 0 were performed for each probe-set on each array, and $\mathrm{P}<0.01$ was used to judge that the associate transcript was detectable. For each array, the largest and smallest $20 \%$ of the PM-MM differences for a probe-set were discarded and the remaining differences averaged to obtain (unnormalised) probe-set intensities. The standard $230 \mathrm{~A}$ array was scaled (every value multiplied by a constant) to provide an average of $1500 \mathrm{U}$, and the remaining A arrays normalised to the standard using a piecewise linear function that made 99 evenly spaced quantiles agree with the quantiles of the standard. We scaled the standard 230B array by using data for nine probe-sets that are identical on the A and B arrays for the standard sample, making the geometric mean of the ratios for these probe-sets equal 1.0. This resulted in the B array standard providing an average over all probesets of $445 \mathrm{U}$. The remaining B arrays were then normalised to the standard B array using the same quantile-normalisation algorithm as used for the A 
arrays. The normalised data were log-transformed using $\log [-$ $\max (x+50,0)+50]$ to perform paired t-tests between fasting and fed samples. Fold-change indices for each pair of samples were obtained by forming the ratio of normalised intensities, except that intensities smaller than $50 \mathrm{U}$ were replaced by 50 . An overall fold-change was computed as the geometric mean of these five individual fold-changes.

To estimate the false positive rate for this selection, we performed the same selection on data sets for which the labels for pairs of fasting and fed samples were permuted in every possible combination that differed from the actual labels. Information about genes was obtained using the National Center for Biotechnology Information (NCBI) database interfaces to LocusLink, UniGene, and HomoloGene, as well as Medline.

\section{Reverse transcription quantitative polymerase chain reaction ( $R T-Q P C R$ )}

RT-QPCR was performed using a BioRad iCycler iQ Real Time PCR Detection System (BioRad Laboratory, Inc., Carlsbad, CA, USA) and FAMlabelled fluorogenic probes. RT-QPCR was performed using the SuperScript One-Step RT-PCR System with Platinum Taq DNA Polymerase (Invitrogen). $10 \mathrm{ng}$ of arcuate nucleus total RNA, gene specific primers and probes were added to each reaction mixture. PCR conditions were RT $\left(48{ }^{\circ} \mathrm{C}, 30 \mathrm{~min}\right)$ followed by PCR amplification (one cycle at $95^{\circ} \mathrm{C}$ for 5 min followed by 60 cycles of $95{ }^{\circ} \mathrm{C}$ for $30 \mathrm{~s} ; 60{ }^{\circ} \mathrm{C}$ for $30 \mathrm{~s} ; 72{ }^{\circ} \mathrm{C}$ for $30 \mathrm{~s}$ ). Triplicate wells were run for each sample. Relative mRNA expression was normalised to GAPDH.

\section{Cloning of the rat Asb-4 cDNA}

The Affymetrix probe-set information annotated Asb-4 mRNA as a transcribed sequence corresponding to UniGene cluster Rn.16079. A BLAST search of the NCBI nucleotide database using the Rn.16079 target sequence identified it as the rat homolog of the mouse Asb- 4 cDNA (GenBank accession no. BC056440). A further BLAST search using the mouse $A s b-4$ sequence as the query sequence identified a rat BAC clone CH230-252C14 (GenBank accession no. AC109666). The mouse and human $A s b-4$ genes are known to have five exons with conserved intron/exon boundaries (40). Comparison of the rat genomic sequence with the mouse sequences revealed that five exons were also present in the rat gene. To generate a rat Asb-4 cDNA, we designed PCR primers according to the sequences of the predicted $5^{\prime}$ start and $3^{\prime}$ stop codons. Each of the primers contained a small amount of 5'- and 3' UTR. The sense primer was 5'-CCC AAG CTT AGG GCT CGG AGG ATG GAC GGC ATC-3'. The antisense primer was $5^{\prime}$-CGG AAT TCT GCG TCT ACC CAG TGA GTC CAC TTA G- ${ }^{\prime}$. The PCR was performed using cDNA generated from microdissected arcuate nucleus total RNA. PCR was performed using TITANIUM TagDNA polymerase plus TagStart antibody (Advantage 2 Enzyme Kit, Invitrogen) and a Perkin-Elmer 480 thermal cycler (Perkin-Elmer, Boston, MA, USA) programmed for one cycle at $95^{\circ} \mathrm{C}$ for 2 min followed by 35 cycles at $95{ }^{\circ} \mathrm{C}$ for $15 \mathrm{~s} ; 60^{\circ} \mathrm{C}$ for $30 \mathrm{~s}$; and $68{ }^{\circ} \mathrm{C}$ for $90 \mathrm{~s}$.

\section{In situ hybridisation}

A 568-bp PCR generated fragment of the rat Asb-4 cDNA (codon 681-1248) was subcloned into pBluescript SK (Stratagene, La Jolla, CA, USA) for in situ hybridisation. The sense primer was: 5'-CGG GAT CCG GAG CAG GAG TAC AGC AGG GAA CA-3'. The antisense primer was $5^{\prime}$-CGG AAT TCT GAC AGT GGG AGG GAC AGC ATA GG-3'. The NPY cDNA (AI045437) in pT7T3D-PAC was purchased from Invitrogen. The rat POMC plasmid construct consisted of an 833-bp insert that included the full coding region of the POMC gene inserted into pGEM4Z (Promega, Madison, WI, USA). The POMC-pGEM4Z plasmid was constructed by R. C. Thompson.

Seven-week-old male Sprague-Dawley rats (weighing 280-300 g) were anaesthetised with ketamine/xylazine and perfused via the ascending aorta with $200 \mathrm{ml}$ of phosphate buffered saline (PBS), followed by $200 \mathrm{ml}$ of $4 \%$ paraformaldehyde in PBS. The brain was postfixed for $16 \mathrm{~h}$ then transferred to $20 \%$ sucrose ( $20 \%$ sucrose in PBS with $0.02 \%$ sodium azide) for 5 days at $4{ }^{\circ} \mathrm{C}$. The brain was embedded with $20 \%$ sucrose and Tissue-Tek OCT $(2: 1)$ and coronal sections of $14 \mu \mathrm{m}$ were cut on a cryostat. The sections were dried overnight at room temperature and were stored at $-80{ }^{\circ} \mathrm{C}$ until further processing. Sections studied covered the telencephalon and diencephlon from coordinates bregma $-0.80 \mathrm{~mm}$ to bregma $-4.16 \mathrm{~mm}$ according to Paxinos and Watson (41).

In situ hybridisation was conducted using a modification of a previously described technique $(42,43)$. The brain sections were washed three times with
$2 \times \mathrm{SSC}$ and then digested with $0.45 \mu \mathrm{g} / \mathrm{ml}$ proteinase $\mathrm{K}$ (Invitrogen) in $100 \mathrm{~mm}$ Tris, $\mathrm{pH} \mathrm{8.0,50} \mathrm{mm} \mathrm{EDTA)} \mathrm{for} 15 \mathrm{~min}$ at $37^{\circ} \mathrm{C}$. After brief washing with distilled water, the sections were acetylated with $0.25 \%$ acetic anhydride in $0.1 \mathrm{~m}$ triethanolamine $(\mathrm{pH} 8.0)$ for $10 \mathrm{~min}$. The sections were subsequently dehydrated through a graded series of ethanols.

The ${ }^{35}$ S-labelled antisense and sense Asb-4 RNA probes, Dig-labelled antisense and sense NPY and POMC RNA probes were generated using standard in vitro transcription methodology (44). Antisense or sense probes (negative control) were diluted in hybridisation buffer $(50 \%$ formamide, $3 \times$ SSC, $1 \times$ Denhart's, $200 \mu \mathrm{g} / \mathrm{ml}$ yeast tRNA, $50 \mathrm{~mm}$ phosphate buffer, $\mathrm{pH} 7.4,10 \%$ dextran sulphate and $10 \mathrm{~mm}$ DTT) to yield approximately $1.2 \times 10^{6}$ c.p.m. $/ 40 \mu \mathrm{l} .40 \mu \mathrm{l}$ diluted probes were applied to each slide and the sections coverslipped. Slides were then placed in sealed plastic boxes lined with filter paper moistened with $50 \%$ formamide. These boxes were wrapped with plastic wrap and incubated at $55^{\circ} \mathrm{C}$ for $16 \mathrm{~h}$.

For single label in situ hybridisation, the sections were hybridised with antisense ${ }^{35} \mathrm{~S}$-labelled Asb-4 riboprobe. For dual label in situ hybridisation, the sections were hybridised with antisense digoxigenin (DIG)-labelled NPY or POMC and Asb- $4{ }^{35} \mathrm{~S}$-labelled riboprobes.

Following overnight incubation, coverslips were removed by dipping in $2 \times$ SSC and the slides were washed with $2 \times$ SSC. Slides were then incubated with $200 \mu \mathrm{g} / \mathrm{ml}$ RNase A (Roche, Indianapolis, IN, USA) in $10 \mathrm{~mm}$ Tris- $\mathrm{HCl}$, $\mathrm{pH} 8.0,0.5 \mathrm{M} \mathrm{NaCl}$ at $37^{\circ} \mathrm{C}$ for $1 \mathrm{~h}$. The slides were washed with $2 \times, 1 \times$, $0.5 \times$ and $0.1 \times \mathrm{SSC}$ at room temperature and then incubated in $0.1 \times \mathrm{SSC}$ at $67^{\circ} \mathrm{C}$ for $1 \mathrm{~h}$. The sections were washed briefly with distilled water. For single label in situ hybridisation, the slides were dehydrated in graded alcohols and air-dried. Dried slides were exposed to Kodak BioMax film (Kodak, Rochester, NY, USA). For dark-field photomicrographs, cells were dipped in Ilford K.5D nuclear emulsion (Ilford Imaging, Mobberley, UK).

For dual label in situ hybridisation, after washing with distilled water, the sections were incubated with anti-DIG antibody (Roche) conjugated with alkaline phosphatase (dilution $1: 20000$ ) overnight at room temperature. The slides were next incubated in nitroblue terazolium chloride and 5-bromo-4chloro-3-indolyl-phosphate solution for 2-4 h and then dipped in Ilford K.5D nuclear emulsion. Sections were developed with D-19 developer. For NPY and POMC colocalisation studies, six fed and six fasted rats were used. For each rat, eight brain sections representing the rostral, middle and caudal portions of the ARC were counted.

\section{Virtual Northern}

Virtual Northern Blots (45) were performed using the Smart PCR cDNA Synthesis Kit (Clontech, Palo Alto, CA, USA).

\section{Results}

\section{Microarray analysis}

Because of the difficulty of reliably finding differences for low-abundance transcripts, we obtained datasets from analysis using Affymetrix software, as well as our own, hoping to improve the robustness of our selection. We first made a preliminary selection that removed all probe-sets for which eight or more of the 10 samples gave an 'absent' call according to Affymetrix's test for the presence of a transcript, or had eight or more samples giving $\mathrm{P}>0.01$ for our own similar test. This left 16695 probe-sets (10 164 on the A array, 6531 on the $\mathrm{B}$ array). We further required that $\mathrm{P}<0.05$ for a paired $T$-test between fasting and fed samples on our logtransformed data, as well as that the average fold-change for the five pairs, be larger than 1.2 (in either direction). This selected 395 probe-sets. A fold-change of greater than or less than 1.2 was chosen based on our previous studies, which also showed small fold changes and indicated that signature mRNAs, such as POMC, NPY and CART, were included by this criterion (46). Finally, we asked that the fold-change estimates in our data, as well as differences in the Affymetrix 
dataset, both had at least four out of the five pairs changing in the same direction, which left 326 probe-sets (230 on array A, and 96 on array B). Because three genes had two probe-sets and one had three, a total of 321 genes were represented by the 326 probe-sets. Spread sheets containing the 326 probesets and a list of the entire 31256 probe-sets examined, as well as the .CEL level data (probe cell data that can be used by the public for additional analysis), are available as supplementary material to this paper.

Permutation testing on the 326 probe-sets (230 on the A chip and 96 on the B chip) obtained an average of 45.4 probesets from the permuted data sets for the A arrays, and 37.0 probe-sets for the B arrays. We thus estimate that $19.7 \%$ of the 230 selected probe-sets on the A arrays are false-positives, and that $38.5 \%$ of the 96 selected probe-sets on the B arrays are false-positives. The overall estimated false discovery rate was $25.3 \%$ for the total set of 326 selected probe-sets.

If 16695 is used as a measure of genes expressed in the arcuate nucleus, then $16695 / 31256$ or $53.4 \%$ of probe-sets are expressed in the arcuate nucleus. The number of genes would be somewhat lower because of multiple probe-sets for a single gene.

Asb-4 (Rn.16079) is categorised under 'Other Proteins' (see Supplementary material). It has two probe-sets. The degree of Asb-4 mRNA down-regulation detected by microarray was -1.31 and -1.34 , which is a greater reduction than that of CART (-1.21), a satiety factor known to be down-regulated with fasting (47).

\section{Reverse transcription quantitative PCR and virtual Northern}

Table 1 lists results of genes that were validated by RTQPCR or virtual Northern. Down-regulation of Asb-4 mRNA in the arcuate nucleus of fasted rats was confirmed (relative expression of Asb-4: fed $=4.66 \pm 0.26$; fas$\mathrm{t}=3.96 \pm 0.23 ; \mathrm{n}=4, \mathrm{P}<0.01)$. To investigate Asb-4 mRNA expression in a second model of energy disequilibrium, we examined the genetically obese Zucker rat $(f a / f a)$. Compared to the lean Zucker rat, Asb-4 mRNA was down- regulated in the arcuate nucleus of the $f a / f a$ rat (Asb-4: lean $=3.91 \pm 0.32 ; f a / f a=2.93 \pm 0.26 ; \mathrm{n}=5 ; \mathrm{P}<0.001)$.

\section{Cloning of the rat Asb-4 cDNA}

The size of the coding region of the rat Asb-4 cDNA is 1281 bp. The rat Asb-4 cDNA sequence was deposited into GenBank (accession number AY577765). There is 94\% nucleotide identity between the rat and mouse sequences in the $A s b-4$ coding region. The PCR product was a single band on $1 \%$ agarose gel electrophoresis. It was subcloned into pcDNA3.1 (Invitrogen) and its sequence confirmed by DNA sequencing. The presence of a single band on agarose gel electrophoresis indicates that a shorter splice variant of $A s b-4$ (GenBank accession number NM_145872) is not present in the arcuate nucleus because this shorter variant would have been generated by our PCR primers (primer sequences presented in the Methods section) and detected as a second band in the gel $231 \mathrm{bp}$ smaller in size.

\section{In situ hybridisation}

Figure 1 shows photomicrographs of the neuroanatomical distribution of Asb-4 mRNA in the hypothalamus and amygdala from rostral (Fig. 1A) to caudal (Fig. 1C). Figure 1(A) corresponds approximately to Fig. 26 in Paxanos and Watson (41). Figure 1(B,C) corresponds approximately to Figs 29 and 30 and Fig. 32 of Paxanos and Watson (41), respectively. Asb-4 mRNA was detected in the arcuate nucleus (ARC), paraventricular nucleus (PVN), periventricular nucleus (Pe), dorsomedial nucleus (DMN), lateral hypothalamus and posterior hypothalamus. In the amygdala Asb-4 mRNA was observed in an area that included the posterodorsal part of the medial amygdaloid nucleus (MePD) and the intra-amygdaloid division of the bed nucleus of the stria terminalis (BSTIA). No specific hybridisation above background occurred when sense probe was used (Fig. 1D).

Figure 2 shows photomicrographs of the neuroanatomical distribution of Asb-4 mRNA using dark field microscopy.

TABLE 1. Genes Validated by Reverse Transcription Quantitative Polymerase Chain Reaction (RT-QPCR) to be Up or DownRegulated. Gene Expression was also Examined in the Genetically Obese $f a / f a$ Rat; TPRA40 was Expressed, but not Regulated.

\begin{tabular}{|c|c|c|c|c|c|c|}
\hline Genes & $\begin{array}{l}\text { Microarray } \\
\text { ratio, fast/fed }\end{array}$ & $\mathrm{P}$ & $\begin{array}{l}\text { RT-QPCR } \\
\text { ratio, fast/fed }\end{array}$ & $\mathrm{P}$ & $\begin{array}{l}\text { RT-QPCR } \\
\text { ratio, } f a / f a / \text { lean }\end{array}$ & $\mathrm{P}$ \\
\hline Asb-4 & 0.75 & 0.003 & 0.85 & 0.002 & 0.75 & 0.007 \\
\hline Stearoyl CoA desaturase 1 & 0.57 & 0.004 & 0.64 & 0.043 & 0.88 & 0.045 \\
\hline Acetyl CoA synthetase 1 & 0.75 & 0.004 & 0.84 & 0.005 & 0.86 & 0.08 \\
\hline HMG CoA synthase 2 & 1.82 & 0.003 & 1.93 & 0.02 & 0.87 & 0.057 \\
\hline Fatty acid binding protein 7 & 0.62 & 0.0016 & 0.62 & 0.012 & 0.54 & 0.03 \\
\hline Insulin-like growth factor II & 0.57 & 0.015 & 0.67 & 0.042 & 0.73 & 0.027 \\
\hline $\begin{array}{l}\text { Insulin-like growth } \\
\text { factor binding protein } 5\end{array}$ & 0.63 & 0.00005 & 0.51 & 0.004 & 0.54 & 0.002 \\
\hline Neuromedin B & 1.89 & 0.003 & 3.0 & 0.016 & 2.01 & 0.035 \\
\hline C-Kit receptor & 0.68 & 0.007 & 0.75 & 0.044 & 0.46 & 0.03 \\
\hline Kruppel-like factor 9 & 1.48 & 0.004 & 1.27 & 0.02 & 0.9 & 0.4 \\
\hline AW435415, EST & 1.75 & 0.002 & 1.74 & 0.001 & 1.23 & 0.144 \\
\hline Prostaglandin D synthase & 0.47 & 0.03 & 0.77 & 0.047 & 0.68 & 0.015 \\
\hline SGK & 1.84 & 0.0008 & $1.99^{\mathrm{a}}$ & 0.008 & $1.42^{\mathrm{a}}$ & 0.0319 \\
\hline Tpra40 & 1.23 & 0.027 & 1.02 & 0.6 & - & \\
\hline
\end{tabular}

${ }^{\mathrm{a}}$ Virtual Northern blot. 
(A)
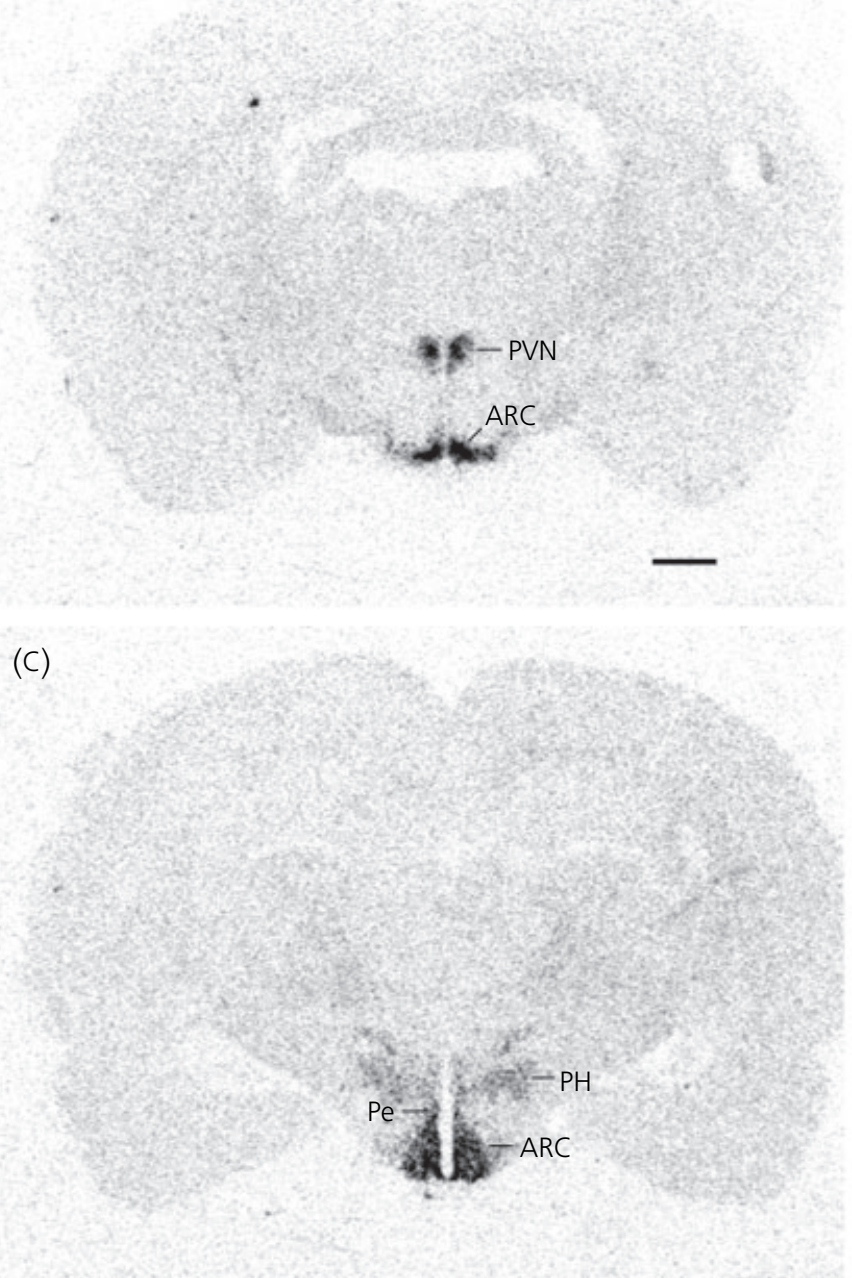

(B)

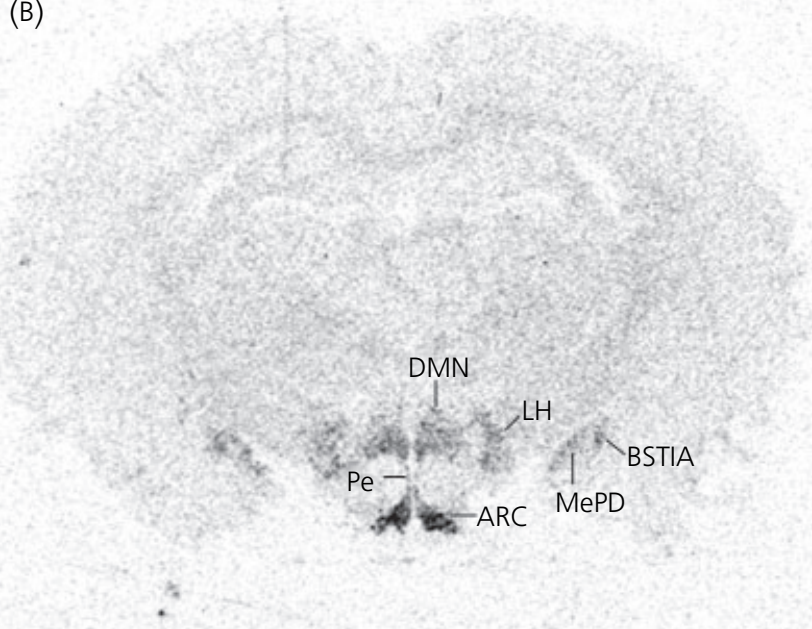

(D)

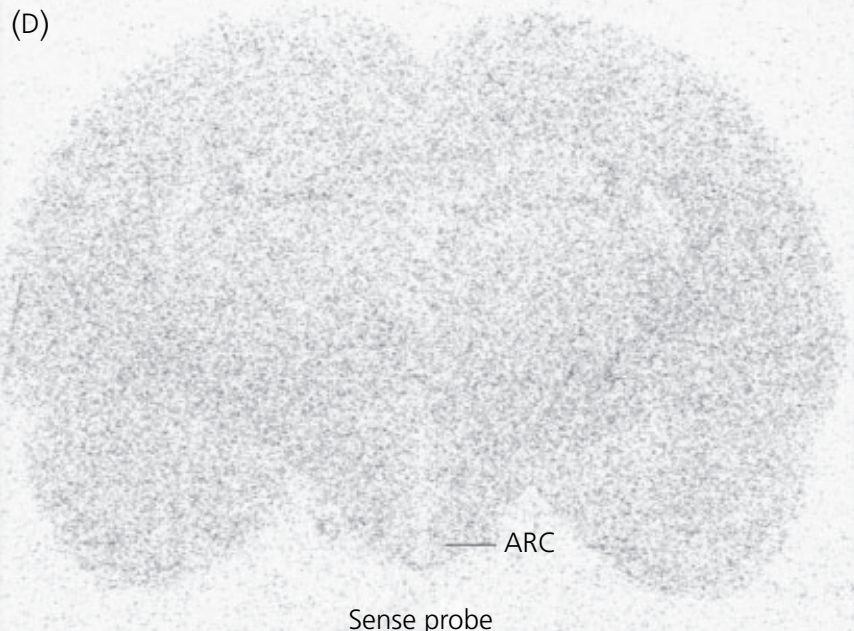

FIG. 1. Photographs showing the neuroanatomical distribution of Asb-4 mRNA. PVN, Paraventricular nucleus; ARC, arcuate nucleus; DMN, dorsomedial nucleus; Pe, periventricular nucleus; LH, lateral hypothalamic area; BSTIA, bed nucleus of the stria terminalis, intra-amygdaloid division; MePD, medial amygdaloid nucleus, postero-dorsal part. Scale bar $=1.0 \mathrm{~mm}$.

Asb-4 mRNA is demonstrated in the paraventricular nucleus (PVN, Fig. 2A), dorsomedial nucleus (DMN, Fig. 2B), lateral hypothalamus (Fig. 2C) and amygdala (Fig. 2D). Within the PVN, Asb-4 mRNA was observed in the parvicellular portion. The broken line outlines the boundaries of the PVN.

Figure 3 shows dark field photomicrographs of Asb-4 mRNA in the rostral and mid-portions of the arcuate nucleus of fed and fasted rats. Figure $3(\mathrm{~A}, \mathrm{~B})$ is representative coronal sections of the rostral arcuate nucleus in the fed and fasted states, respectively. A marked down-regulation in Asb-4 mRNA occurs in the rostral arcuate nucleus in the fasted state. A smaller degree of down-regulation is observed in the mid-portion of the arcuate nucleus (Fig. 3C,D). Of note, lateral cellular elements in Fig. 3(C,D) show a greater change than medial elements. This is compatible with the known POMC neurone localisation, which is predominantly in the lateral arcuate nucleus.

Figure 4 shows photomicrographs of double in situ hybridisations in the arcuate nucleus. Blue represents digoxigenin labelled POMC neurones (Fig. 4A,B) and NPY neurones
(Fig. 4C,D). Arrows indicate double labelled neurones. Figure 4(A) is representative of the fed rat. Dense clustering of silver grains, which represent Asb-4 mRNA, is present over POMC neurones in the fed state. Figure 4(B) is representative of the fasted rat. The density of silver grains is markedly lower over POMC neurones, indicating much less expression of Asb-4 mRNA per POMC neurone in the fasted state. Figure 4(C,D) shows NPY neurones in the fed and fasted states. Compared to POMC neurones, NPY neurones have much fewer silver grains in the fed state (Fig. 4C). A small, but statistically significant increase in NPY neurone Asb-4 mRNA expression was observed in fasted rats (Fig. 4D).

In the fed state, $95.6 \pm 0.5 \%$ of POMC neurones and $46.4 \pm 1.6 \%$ of NPY neurones express Asb- 4 mRNA. In the fasted rat, the number of POMC neurones expressing Asb-4 mRNA drops to $73.2 \pm 2.2 \%(\mathrm{P}<0.001)$. The number of NPY neurones expressing Asb-4 mRNA in the fasted state was modestly increased to $52.7 \pm 1.9 \% \quad(\mathrm{P}<0.05)$. Co-localisation was defined as the presence of silver grains four-fold greater than background. 

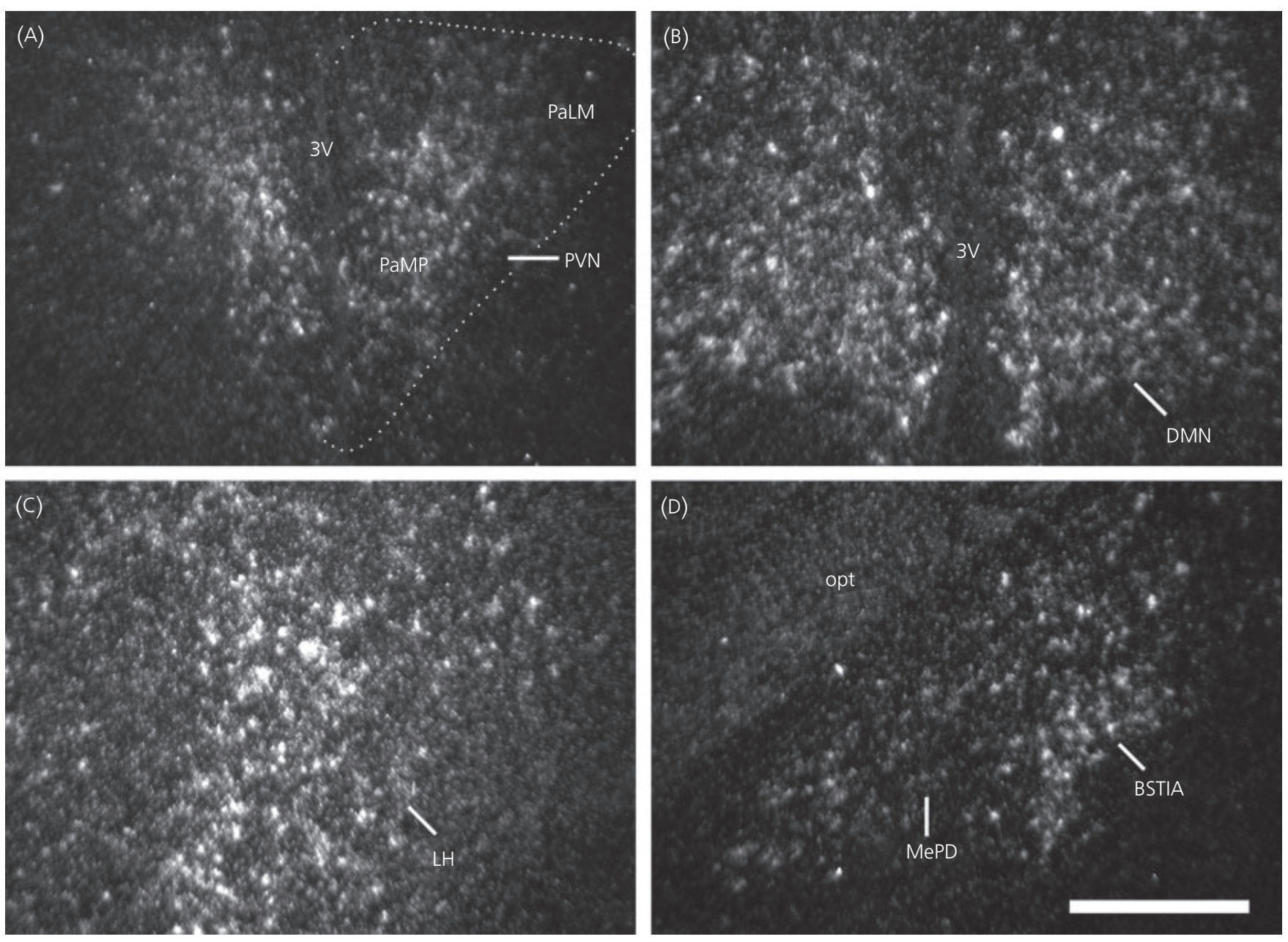

Fig. 2. Dark field photomicrograph showing Asb-4 mRNA in the (A) PVN, paraventricular nucleus; PaMp, paraventricular nucleus medial parvocellular part; $\mathrm{PaLM}$, paraventricular nucleus lateral magnocellular part; the broken line outlines the periphery of the PVN and shows that Asb-4 mRNA is not expressed in magnocellular neurones; 3V, third ventricle; (в) DMN, dorsomedial nucleus; (с) LH, lateral hypothalamus; (D) MePD, medial amigdaloid nucleus, posterodorsal part; BSTIA, bed nucleus of the stria terminalis, intra-amygdaloid division; opt, optic tract. Scale bar $=500 \mu \mathrm{m}$.

\section{Discussion}

The arcuate nucleus is believed to sense and integrate blood borne and afferent central nervous system signals that are indices of nutrient balance. Our experiment explores the transcriptome that subserves those functions.

Our list of candidate arcuate nucleus energy homeostatic genes contains many familiar in arcuate nucleus physiology including NPY, CART, suppressor of cytokine signalling-3 (48), signal transducer and activator of transcription-3 (49) and insulin receptor substrate-1 (50) (see Supplementary material). The list also drew our attention to proteins less well known for their association with feeding behaviour, including insulin-like growth factor II (51), neuromedin B (52), neurotensin (53), diazepam binding inhibitor (the precursor of octadecaneuropeptide) (54) and growth hormone releasing hormone (55). Our list also identifies a well developed pathway for lipid metabolism. This is of potential significance because monounsaturated long chain fatty acids such as oleic acid are potent anorexigens (56). Interestingly, stearoyl-CoA desaturase-1, one of the down-regulated
mRNAs, is a key enzyme in the production of monounsaturated long chain fatty acids such as oleic acid and has previously been shown to be a leptin-regulated gene (57). Notably, another regulated mRNA, fatty acid binding protein-7 prefers $\mathrm{C}: 18$ monounsaturated fatty acids such as oleic acid (58). Modulation of long chain fatty acid levels locally in the arcuate nucleus may be an important component of energy homeostasis. Adenylate monophosphate-activated kinase has recently been identified as a monitor of cellular energy stores in the hypothalamus (59). The alpha 1 catalytic and gamma 2 non-catalytic subunits of the adenylate monophosphate-activated kinase were identified as oppositely regulated mRNAs in this study. Transcripts chosen for validation to date are listed in Table 1. Concordance of RT-QPCR results between the 48-h fasted rat and the genetically obese $f a / f a$ rat was common but not universal. We viewed the $f a / f a$ rat as second model of energy disequilibrium and interpreted concordance as an additional piece of evidence implicating a transcript in energy homeostasis, although lack thereof does not exclude that function. 

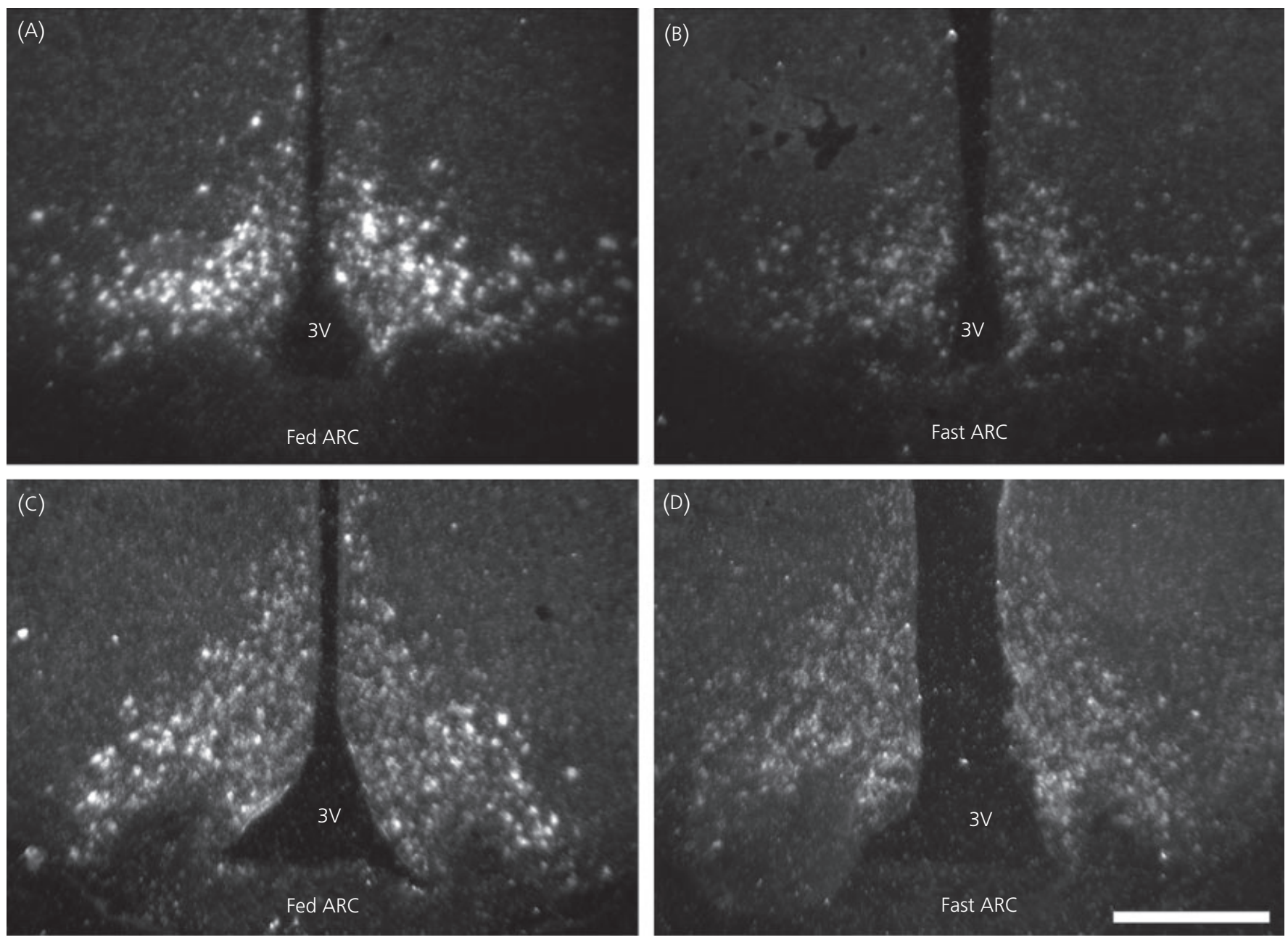

FIG. 3. Dark field photomicrograph showing Asb-4 mRNA in the rostral and mid-portion of the arcuate nucleus in the fed and fasted rat; Asb-4 mRNA expression is greater in the (A) rostral arcuate nucleus than the (C) mid- arcuate nucleus of the fed animal. With fasting, there is a greater down-regulation of Asb-4 mRNA in the (в) rostral arcuate nucleus than in the (D) mid-arcuate nucleus. Scale bar $=500 \mu \mathrm{m}$.

$A s b-4$ was chosen from among our list of candidate genes for more detailed study because of its unique structural features. Based on existing knowledge of the functions of ankyrin repeats and suppressor of cytokine signalling (SOCS) boxes (see below), we hypothesised that $A s b-4$ might have a novel role in the intracellular regulation of energy homeostasis. Our neuroanatomical data support this proposed function. NPY/AGRP and POMC/CART neurones are central to arcuate nucleus physiology and efferent projections from those neurones to 'secondary' energy homeostatic neurones in intra- and extra-hypothalamic sites are a key feature of energy homeostatic circuitry. In the lateral hypothalamus, projections from NPY/AGRP and POMC/CART neurones innervate neurones that express the orexigens melanin concentrating hormone $(\mathrm{MCH})$ and orexin $\mathrm{A}$ and B $(60,61)$. In the paraventricular nucleus, NPY/CART and POMC/AGRP projections innervate neurones that express corticotropin releasing hormone and thyrotropin releasing hormone $(26,28-31,62)$. The ventromedial nucleus, dorsomedial nucleus are additional energy homeostatic hypothalamic nuclei that receive projections from the arcuate nucleus $(16,17,63)$. The periventricular nucleus also receives fibres from the arcuate nucleus (17) and, although it has not classically been considered an energy homeostatic nucleus, the recent report of ghrelin cell bodies in the periventricular nucleus challenges that classification (64). A major finding of our study was that Asb-4 mRNA is expressed in all of these energy homeostatic associated areas, with the conspicuous exception of the ventromedial nucleus. In view of the prominence of NPY/AGRP and POMC/CART neurones in energy homeostasis, it is quite significant that Asb-4 mRNA is differentially expressed by those neurones. We also observed Asb-4 mRNA in the posterior hypothalamus, an area that has not been associated with energy homeostasis. However, the posterior hypothalamus is thought to be involved in behavioural arousal and autonomic regulation (65), processes that closely interface with energy homeostasis. Supporting the existence of this interface is the observation that core elements of the energy homeostatic network are expressed in the posterior hypothalamus, including leptin receptors (66), MC3R and MC4R $(67,68), \mathrm{MCH}$ neurones (69) and $\gamma$-MSH and AGRP fibres (24). Orexin neurones, which modulate feeding behaviour and arousal, are also present (60). 
Fed POMC
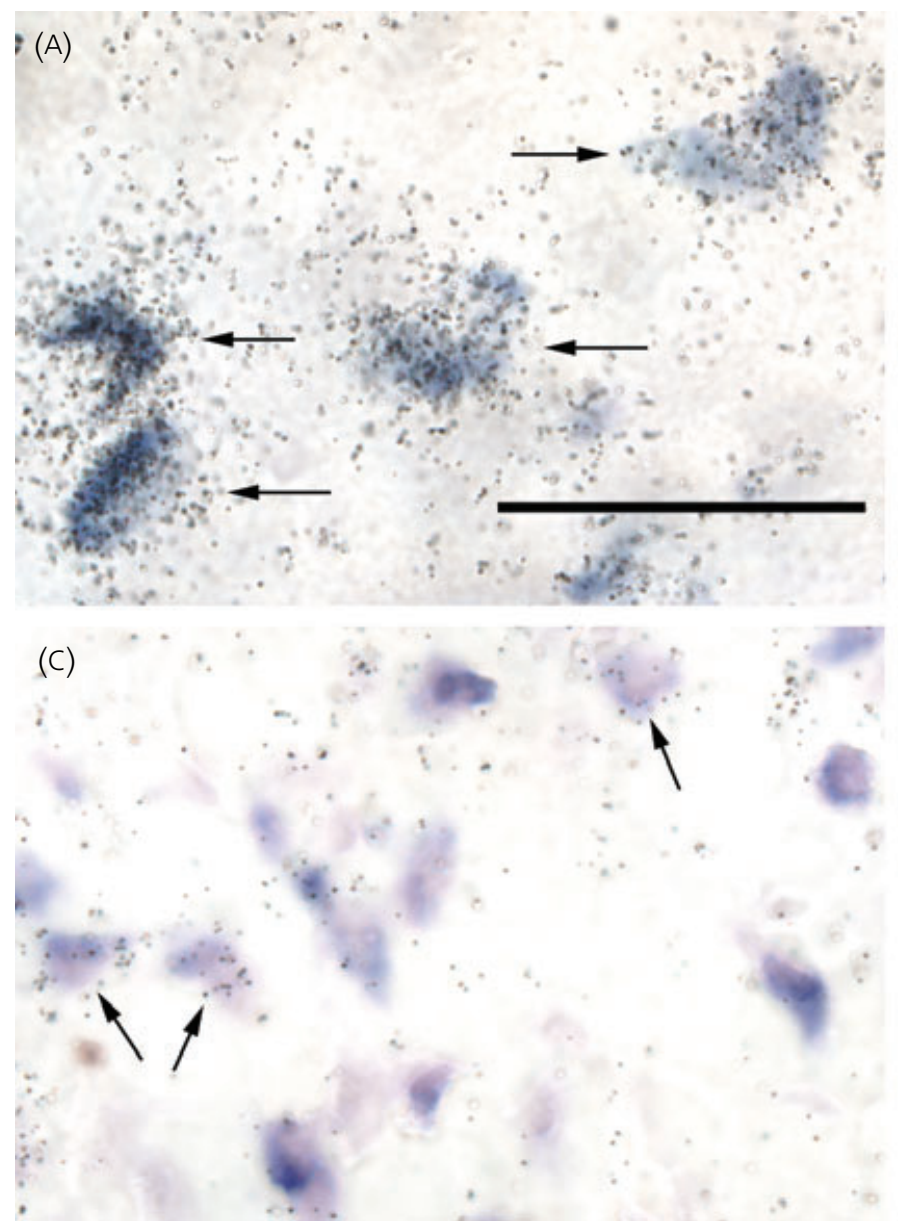

Fed NPY
Fast POMC

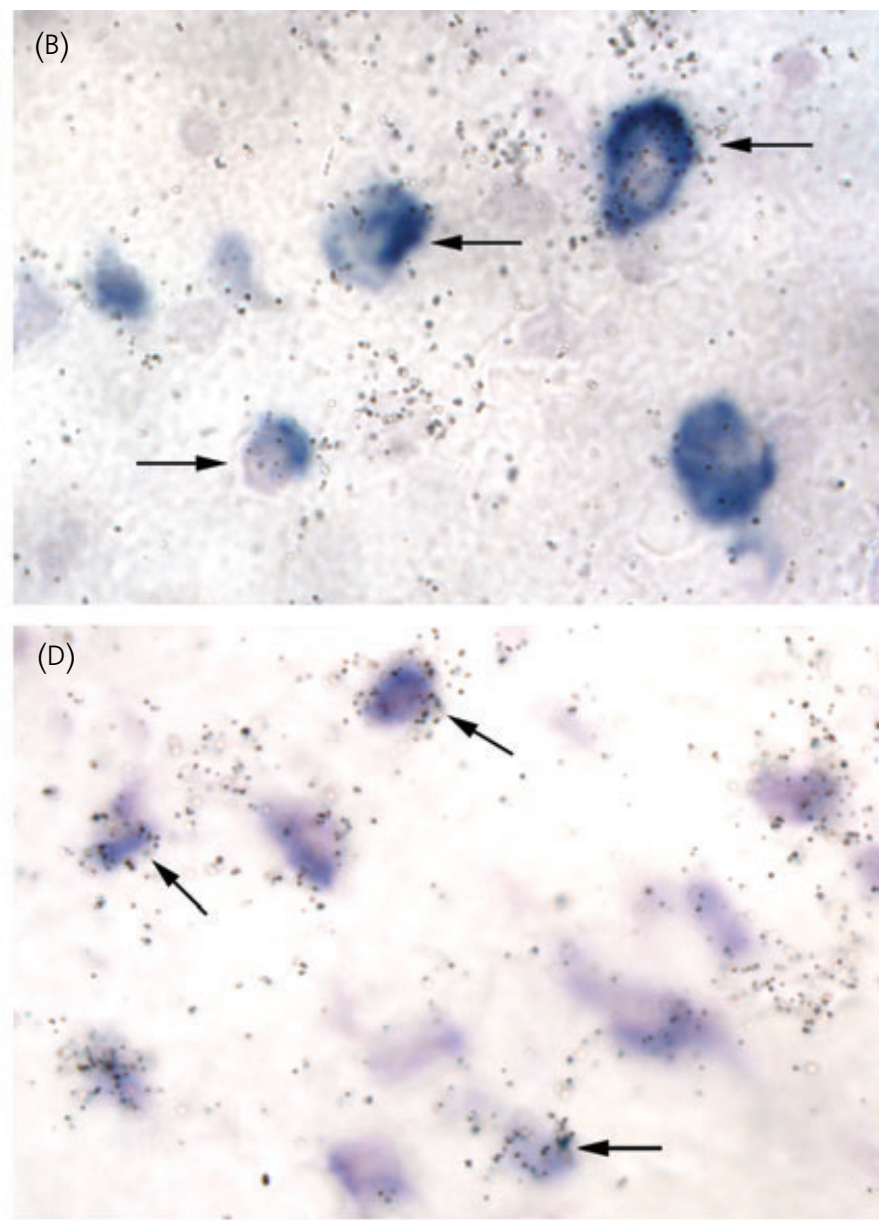

Fast NPY

FIG. 4. Photomicrographs of double in situ hybridisations demonstrating colocalisation of Asb-4 mRNA with pro-opiomelanocortin (POMC) (A,B) and neuropeptide Y (NPY) (C,D) neurones. Blue represents digoxigenin labelled POMC and NPY neurones. Silver grains indicate Asb-4 mRNA. Arrows indicate POMC or NPY neurones where colocalisation of Asb-4 mRNA is observed. Scale bar $=50 \mu \mathrm{m}$.

In the amygdala, Asb-4 mRNA is found in the MePD and the BSTIA, which are areas that have been implicated in feeding behaviour. Electrolytic lesioning of this area has been shown to cause hyperphagia (70). In addition to this functional data, neuroanatomical studies implicate the MePD and BSTIA in feeding behaviour. Hypothalamic neurones from feeding-related centres, such as the arcuate nucleus, lateral hypothalamus and paraventricular nucleus, project to the MePD and BSTIA $(71,72)$. Arcuate nucleus projections to the MePD and BSTIA include those immunoreactive for $\gamma$-MSH and AGRP (24). MC4R receptors are expressed in the MePD and BST (68). Of note, mice with diet-induced obesity were observed to have a $40 \%$ up-regulation of MC4R mRNA in the MePD (73). In addition, $\mathrm{MCH}$ receptor-1 and $\mathrm{MCH}$ immunoreactive fibres are found in the posteromedial amygdala and BST $(70,74)$. Posterior hypothalamus projections to the MePD and BSTIA have also been noted $(69,75)$.

$A s b-4$ was originally identified by database search using a SOCS box consensus sequence (40). There are five major protein families that have SOCS boxes (76). They differ in the type of domain that is upstream of the SOCS box and include: (i) SH2 domain proteins with a SOCS box; (ii) ankyrin repeat proteins with a SOCS box; (iii) SPRY-domain (a domain found in Dictyostelium discodeum dual-specificity kinase $s p 1 \mathrm{~A}$ and mammalian ryanodine receptor subtypes) proteins with a SOCS box; (iv) WD40-repeat proteins with a SOCS box; and (v) a family of small rar-like GTPases with a SOCS box.

Within the context of metabolic regulation, SOCS-3 is well known. It has been shown to down-regulate leptin receptor and insulin receptor signalling $(47,77)$. However, SOCS-3 belongs to the SH2 domain family of SOCS box proteins whereas Asb-4 belongs to the ankyrin repeat family.

Asb-4 has nine ankyrin repeats $\mathrm{N}$-terminal to its SOCS box. Ankyrin repeats are loosely conserved sequences of approximately 33 amino acids (78). Each repeat is a helix-loop-helix structure with a $\beta$-hairpin region that projects outward from the helices at a $90^{\circ}$ angle. Ankyrin repeat domains are thought to be the site of specific protein-protein interaction.

To date, 18 Asb proteins have been isolated (76). Several Asb proteins have been identified within the setting of a 
physiological process, but no commonality is obvious (7981). An $A s b-1$ null mouse was generated, but was not informative with respect to to the function of $A s b-1$ or the Asb protein family as a whole (82). Recently, Asb-6 was identified as an adipocyte-specific protein that modulates APS interaction with the insulin receptor (83).

Asb-4 is an imprinted gene on human chromosome 7q21-22 (84). Two isoforms are entered in GenBank. Isoform $\mathrm{b}$ has a shorter and distinct C-terminus, which lacks the SOCS box domain. This implies a functional difference between isoforms. Two isoforms have not been documented in the rat. In our study, only the long form was observed in the arcuate nucleus.

It has been suggested that all SOCS box proteins have two functional domains. The first is a domain upstream from the SOCS box where unique protein-protein interactions occur. The second is a SOCS box domain, which serves as a generic adapter site for the elongin $\mathrm{BC}$ components of the E3 ubiquitin ligase complex (76). Members of the SOCS, rar, WD-40 repeat and ankyrin repeat families of SOCS proteins are capable of binding elongin $\mathrm{BC}$ in vitro (85). Within the Asb family, Asb-1, -2, -6 and -8 have been examined and are capable of binding elongin BC in vitro (83, 85-87). Furthermore, examination of the Asb-4 protein sequence indicates it has the consensus elongin $\mathrm{BC}$ binding sequence $(\mathrm{T}, \mathrm{S}, \mathrm{P}) \operatorname{LXXX}(\mathrm{C}, \mathrm{S}) \mathrm{XXX}(\mathrm{L}, \mathrm{I}, \mathrm{V})$ in the $\mathrm{N}$-terminal part of its SOCS box. If Asb-4 conforms to these conventions, it would be predicted that its ankyrin repeat domain binds a specific epitope expressed by a single target protein or class of proteins and that its SOCS box domain regulates proteasomal degradation $(76,88)$.

In summary, we have used oligonucleotide arrays to identify 321 candidate arcuate nucleus energy homeostatic genes. This list and the inclusive list of genes expressed in the arcuate nucleus are a rich source of data for future studies. We have identified $A s b-4$ as a gene whose mRNA is downregulated in the fasted and $f a / f a$ rat and whose expression is restricted to energy homeostasis-related brain centres. Two neuronal types, POMC and NPY, which are critical sensors of peripheral caloric status differentially express Asb-4 mRNA. Taken together, we hypothesise that $A s b-4$ encodes an intracellular regulatory protein within CNS energy homeostatic circuits. Identification of proteins that bind Asb-4 and demonstration of homeostatic changes induced by manipulation of Asb-4 mRNA expression will further elucidate the function of this transcript.

\section{Acknowledgements}

This work was supported by NIDDK 2RO1 DK054032-06, the University of Michigan Gastrointestinal Peptide Research Center (NIH P30DK34933), and the Michigan Diabetes Research and Training Center (NIH 5P60 DK20572).

\section{Supplementary material}

Supplementary material for this paper is available at http://www.blackwell publishing.com/products/journals/suppmat/JNE/JNE1317/JNE1317sm.htm.

Accepted 11 April 2005

\section{References}

1 Schwartz MW, Woods SC, Porte D Jr, Seeley RJ, Baskin DG. Central nervous system control of food intake. Nature 2000; 404: 661-671.

2 Korner J, Leibel R. To eat or not to eat - how the gut talks to the brain. $N$ Engl J Med 2003; 349: 926-928.

3 Marx J. Cellular warriors at the battle of the bulge. Science 2003; 299: 846-849.

4 Flint A, Raben A, Astrup A, Holst JJ. Glucagon-like peptide 1 promotes satiety and suppresses energy intake in humans. J Clin Invest 1998; 101: 515-520.

5 Naslund E, Barkeling B, King N, Gutniak M, Blundell JE, Holst JJ, Rossner S, Hellstrom PM. Energy intake and appetite are suppressed by glucagon-like peptide-1 (GLP-1) in obese men. Int $J$ Obes Relat Metab Disord 1999; 23: 304-311.

6 Larsen PJ, Vrang N, Tang-Christensen M, Jensen PB, Hay-Schmidt A, Romer J, Bjerre-Knudsen L, Kristensen P. Ups and downs for neuropeptides in body weight homeostasis: pharmacological potential of cocaine amphetamine regulated transcript and pre-proglucagon-derived peptides. Eur J Pharmacol 2002; 440: 159-172.

7 Dakin CL, Gunn I, Small CJ, Edwards CM, Hay DL, Smith DM, Ghatei MA, Bloom SR. Oxyntomodulin inhibits food intake in the rat. Endocrinology 2001; 142: 4244-4250.

8 Cohen MA, Ellis SM, Le Roux CW, Batterham RL, Park A, Patterson M, Frost GS, Ghatei MA, Bloom SR. Oxyntomodulin suppresses appetite and reduces food intake in humans. $J$ Clin Endocrinol Metab 2003; 88: 4696-4701.

9 Katsuura G, Asakawa A, Inui A. Roles of pancreatic polypeptide in regulation of food intake. Peptides 2002; 23: 323-329.

10 Batterham RL, Le Roux CW, Cohen MA, Park AJ, Ellis SM, Patterson M, Frost GS, Ghatei MA, Bloom SR. Pancreatic polypeptide reduces appetite and food intake in humans. $J$ Clin Endocrinol Metab 2003; 88: 3989-3992.

11 Asakawa A, Inui A, Yuzuriha H, Ueno N, Katsuura G, Fujimiya M, Fujino MA, Niijima A, Meguid MM, Kasuga M. Characterization of the effects of pancreatic polypeptide in the regulation of energy balance. Gastroenterology 2003; 124: 1325-1336.

12 Druce MR, Small CJ, Bloom SR. Gut peptides regulating satiety. Endocrinology 2004; 145: 2660-2665.

13 Havel PJ, Larsen PJ, Cameron JL. Control of food intake. In: Nemeroff CB, eds. Neuroendocrinology. Boca Raton: CRC Press, 1992: 335-352.

14 Grill HJ, Kaplan JM. The neuroanatomical axis for control of energy balance. Front Neuroendocrinol 2002; 23: 2-40.

15 Date Y, Murakami N, Toshinai K, Matsukura S, Niijima A, Matsuo $\mathrm{H}$, Kangawa $\mathrm{K}$, Nakazato $\mathrm{M}$. The role of the gastric afferent vagal nerve in ghrelin-induced feeding and growth hormone secretion in rats. Gastroenterology 2002; 123: 1120-1128.

16 Palkovits M, Záborszky L. Neural connections of the hypothalmus. In: Morgane PJ, Panksepp J, eds. Handbook of the Hypothalamus, vol. 1. Anatomy of the Hypothalamus. New York: Marcel Dekker, Inc., 1979: 379-509.

17 Chronwall BM. Anatomy and physiology of the neuroendocrine arcuate nucleus. Peptides 1985; 6 (Suppl. 2): 1-11.

18 Fan W, Boston BA, Kesterson RA, Hruby VJ, Cone RD. Role of melanocortinergic neurons in feeding and the agouti obesity syndrome. Nature 1997; 385: 165-168.

19 Rossi M, Kim MS, Morgan DG, Small CJ, Edwards CM, Sunter D, Abusnana S, Goldstone AP, Russell SH, Stanley SA, Smith DM, Yagaloff K, Ghatei MA, Bloom SR. A C-terminal fragment of Agouti-related protein increases feeding and antagonizes the effect of alpha-melanocyte stimulating hormone in vivo. Endocrinology 1998; 139: $4428-4431$.

20 Kalra SP, Kalra PS. Neuropeptide Y a physiological orexigen modulated by the feedback action of ghrelin and leptin. Endocrine 2003; 22: 49-56.

21 Hahn TM, Breininger JF, Baskin DG, Schwartz MW. Coexpression of Agrp and NPY in fasting-activated hypothalamic neurons. Nature Neurosci 1998; 1: 271-272.

22 Broberger C, Visser TJ, Kuhar MJ, Hokfelt T. Neuropeptide Y innervation and neuropeptide-Y-Y1-receptor-expressing neurons in the paraventricular hypothalamic nucleus of the mouse. Neuroendocrinology 1999; 70: 295-305. 
23 Elias CF, Lee CE, Kelly JF, Ahima RS, Kuhar M, Saper CB, Elmquist JK. Chemically defined projections linking the mediobasal hypothalamus and the lateral hypothalamic area. J Comp Neurol 2001; 432: 1-19.

24 Bagnol D, Lu XY, Kaelin CB, Day HE, Ollmann M, Gantz I, Akil H, Barsh GS, Watson SJ. Anatomy of an endogenous antagonist: relationship between Agouti-related protein and proopiomelanocortin in brain. $J$ Neurosci 1999; 19: RC26.

25 Haskell-Luevano C, Chen P, Li C, Chang K, Smith MS, Cameron $\mathrm{JL}$, Cone RD. Characterization of the neuroanatomical distribution of agouti-related protein immunoreactivity in the rhesus monkey and the rat. Endocrinology 1999; 140: 1408-1415.

26 Légrádi G, Lechan RM. The arcuate nucleus is the major source for neuropeptide Y-innervation of thyrotropin-releasing hormone neurons in the hypothalamic paraventricular nucleus. Endocrinology 1998; 139: 3262-3270.

27 Fekete C, Légrádi G, Mihaly E, Huang QH, Tatro JB, Rand WM, Emerson $\mathrm{CH}$, Lechan RM. Alpha-melanocyte-stimulating hormone is contained in nerve terminals innervating thyrotropin-releasing hormone-synthesizing neurons in the hypothalamic paraventricular nucleus and prevents fasting-induced suppression of prothyrotropinreleasing hormone gene expression. J Neurosci 2000; 20: 1550-1558.

28 Li C, Chen P, Smith MS. Corticotropin releasing hormone neurons in the paraventricular nucleus are direct targets for neuropeptide $\mathrm{Y}$ neurons in the arcuate nucleus: an anterograde tracing study. Brain Res 2000; 854: 122-129.

29 Mihály E, Fekete C, Tatro JB, Liposits Z, Stopa EG, Lechan RM. Hypophysiotropic thyrotropin-releasing hormone-synthesizing neurons in the human hypothalamus are innervated by neuropeptide $\mathrm{Y}$, agouti-related protein, and alpha-melanocyte-stimulating hormone. $J$ Clin Endocrinol Metab 2000; 85: 2596-2603.

30 Mihály E, Fekete C, Lechan RM, Liposits Z. Corticotropin-releasing hormone-synthesizing neurons of the human hypothalamus receive neuropeptide $\mathrm{Y}$-immunoreactive innervation from neurons residing primarily outside the infundibular nucleus. J Comp Neurol 2002; 446: 235-243.

31 Lu XY, Barsh GS, Akil H, Watson SJ. Interaction between alphamelanocyte-stimulating hormone and corticotropin-releasing hormone in the regulation of feeding and hypothalamo-pituitary-adrenal responses. J Neurosci 2003; 23: 7863-7872.

32 Erickson JC, Hollopeter G, Palmiter RD. Attenuation of the obesity syndrome of ob/ob mice by the loss of neuropeptide Y. Science 1996; 274: 1704-1707.

33 Huszar D, Lynch CA, Fairchild-Huntress V, Dunmore JH, Fang Q, Berkemeier LR, Gu W, Kesterson RA, Boston BA, Cone RD, Smith FJ, Campfield LA, Burn P, Lee F. Targeted disruption of the melanocortin-4 receptor results in obesity in mice. Cell 1997; 88: 131141.

34 Yaswen L, Diehl N, Brennan MB, Hochgeschwender U. Obesity in the mouse model of pro-opiomelanocortin deficiency responds to peripheral melanocortin. Nature Med 1999; 5: 1066-1070.

35 Ollmann MM, Wilson BD, Yang YK, Kerns JA, Chen Y, Gantz I, Barsh GS. Antagonism of central melanocortin receptors in vitro and in vivo by agouti-related protein. Science 1997; 278: 135-138.

36 Fong TM, Mao C, MacNeil T, Kalyani R, Smith T, Weinberg D, Tota MR, Van der Ploeg LH. ART (protein product of agoutirelated transcript) as an antagonist of MC-3 and MC-4 receptors. Biochem Biophys Res Commun 1997; 237: 629-631.

37 Rosenfeld RD, Zeni L, Welcher AA, Narhi LO, Hale C, Marasco J, Delaney J, Gleason T, Philo JS, Katta V, Hui J, Baumgartner J, Graham M, Stark KL, Karbon W. Biochemical, biophysical, and pharmacological characterization of bacterially expressed human agouti-related protein. Biochemistry 1998; 37: 16041-16052.

38 Butler AA, Kesterson RA, Khong K, Cullen MJ, Pelleymounter MA, Dekoning J, Baetscher M, Cone RD. A unique metabolic syndrome causes obesity in the melanocortin-3 receptor-deficient mouse. Endocrinology 2000; 141: 3518-3521.

39 Chen AS, Marsh DJ, Trumbauer ME, Frazier EG, Guan XMYuH, Rosenblum CI, Vongs A, Feng Y, Cao L, Metzger JM, Strack AM, Camacho RE, Mellin TN, Nunes CN, Min W, Fisher J, Gopal-Truter S, MacIntyre DE, Chen HY, Van der Ploeg LH. Inactivation of the mouse melanocortin-3 receptor results in increased fat mass and reduced lean body mass. Nature Genet 2000 ; 26: $97-102$.
40 Kile BT, Viney EM, Willson TA, Brodnicki TC, Cancilla MR, Herlihy AS, Croker BA, Baca M, Nicola NA, Hilton DJ, Alexander WS. Cloning and characterization of the gene encoding the ankyrin repeat and SOCS box-containing proteins Asb-1, Asb-2, Asb-3 and Asb-4. Gene 2000; 258: 31-41.

41 Paxinos G, Watson C. The Rat Brain in Stereotaxic Coordinates, 4th edn. New York: Academic Press, 1998: 26-34.

42 Schafer MKH, Herman JP, Watson SJ. In situ hybridization histochemistry. In: London E, ed. Imaging Drug Action in the Brain. Boca Raton: CRC Press, 1993: 337-378.

43 Richardson HN, Parfitt DB, Thompson RC, Sisk CL. Redefining gonadotropin-releasing hormone $(\mathrm{GnRH})$ cell groups in the male Syrian hamster: testosterone regulates GnRH mRNA in the tenia tecta. J Neuroendocrinol 2002; 14: 375-383.

44 Sambrook J, Fritsch EF, Maniatis T, eds. Molecular Cloning: A Laboratory Manual, 2nd edn. Cold Spring Harbor, NY: Cold Spring Harbor Laboratory, 1989: 10.29-10.33.

45 Hammerle K, Shayan P, Niemeyer CM, Flotho C. Expression analysis of alpha-NAC and ANX2 in juvenile myelomonocytic leukemia using SMART polymerase chain reaction and 'virtual Northern' hybridization. Cancer Genet Cytogenet 2003; 142: 149-152.

46 Li JY, Lescure PA, Misek DE, Lai YM, Chai BX, Kuick R, Thompson RC, Demo RM, Kurnit DM, Michailidis G, Hanash SM, Gantz I. Food deprivation-induced expression of minoxidil sulfotransferase in the hypothalamus uncovered by microarray analysis. J Biol Chem 2002; 277: 9069-9076.

47 Kristensen P, Judge ME, Thim L, Ribel U, Christjansen KN, Wulff BS, Clausen JT, Jensen PB, Madsen OD, Vrang N, Larsen PJ, Hastrup S. Hypothalamic CART is a new anorectic peptide regulated by leptin. Nature 1998; 393: 72-76.

48 Bjorbaek C, El-Haschimi K, Frantz JD, Flier JS. The role of SOCS3 in leptin signaling and leptin resistance. J Biol Chem 1999; 274: 30059-30065.

49 Bates SH, Stearns WH, Dundon TA, Schubert M, Tso AW, Wang Y, Banks AS, Lavery HJ, Haq AK, Maratos-Flier E, Neel BG, Schwartz MW, Myers MG Jr. STAT3 signalling is required for leptin regulation of energy balance but not reproduction. Nature 2003; 421: 856-859.

50 Niswender KD, Morrison CD, Clegg DJ, Olson R, Baskin DG, Myers MG Jr, Seeley RJ, Schwartz MW. Insulin activation of phosphatidylinositol 3-kinase in the hypothalamic arcuate nucleus: a key mediator of insulin-induced anorexia. Diabetes 2003; 52: $227-$ 231 .

51 Lauterio TJ, Marson L, Daughaday WH, Baile CA. Evidence for the role of insulin-like growth factor II (IGF-II) in the control of food intake. Physiol Behav 1987; 40: 755-758.

52 Merali Z, McIntosh J, Anisman H. Role of bombesin-related peptides in the control of food intake. Neuropeptides 1999; 33: 376-386.

53 Remaury A, Vita N, Gendreau S, Jung M, Arnone M, Poncelet M, Culouscou JM, Le Fur G, Soubrie P, Caput D, Shire D, Kopf M, Ferrara P. Targeted inactivation of the neurotensin type 1 receptor reveals its role in body temperature control and feeding behavior but not in analgesia. Brain Res 2002; 953: 63-72.

54 Compere V, Li S, Leprince J, Tonon MC, Vaudry H, Pelletier G. Effect of intra-cerebro-ventricular administration of the octadecaneuropeptide on the expression of pro-opiomelanocortin, neuropeptide $\mathrm{Y}$ and corticotropin-releasing hormone mRNAs in rat hypothalamus. J Neuroendocrinol 2003; 15: 197-203.

55 Bruno JF, Olchovsky D, White JD, Leidy JW, Song J, Berelowitz M. Influence of food deprivation in the rat on hypothalamic expression of growth hormone-releasing factor and somatostatin. Endocrinology 1990; 127: 2111-2116.

56 Obici S, Feng Z, Morgan K, Stein D, Karkanias G, Rossetti L. Central administration of oleic acid inhibits glucose production and food intake. Diabetes 2002; 51: 271-275.

57 Cohen P, Miyazaki M, Socci ND, Hagge-Greenberg A, Liedtke W, Soukas AA, Sharma R, Hudgins LC, Ntambi JM, Friedman JM. Role for stearoyl-CoA desaturase-1 in leptin-mediated weight loss. Science 2002; 297: 240-243.

58 Hertzel AV, Bernlohr DA. The mammalian fatty acid-binding protein multigene family: molecular and genetic insights into function. Trends Endocrinol Metab 2000; 11: 175-180.

59 Minokoshi Y, Alquier T, Furukawa N, Kim YB, Lee A, Xue B, Mu J, Foufelle F, Ferre P, Birnbaum MJ, Stuck BJ, Kahn BB. 
AMP-kinase regulates food intake by responding to hormonal and nutrient signals in the hypothalamus. Nature 2004; 428: 569-574.

60 Broberger C, De Lecea L, Sutcliffe JG, Hokfelt T. Hypocretin/orexin- and melanin-concentrating hormone-expressing cells form distinct populations in the rodent lateral hypothalamus: relationship to the neuropeptide $\mathrm{Y}$ and agouti gene-related protein systems. J Comp Neurol 1998; 402: 460-474.

61 Elias CF, Saper CB, Maratos-Flier E, Tritos NA, Lee C, Kelly J, Tatro JB, Hoffman GE, Ollmann MM, Barsh GS, Sakurai T, Yanagisawa M, Elmquist JK. Chemically defined projections linking the mediobasal hypothalamus and the lateral hypothalamic area. J Comp Neurol 1998; 402: 442-459.

62 Légrádi G, Lechan RM. Agouti-related protein containing nerve terminals innervate thyrotropin-releasing hormone neurons in the hypothalamic paraventricular nucleus. Endocrinology 1999; 140: 3643-3652.

63 Kalra SP, Dube MG, Pu S, Xu B, Horvath TL, Kalra PS. Interacting appetite-regulating pathways in the hypothalamic regulation of body weight. Endocr Rev 1999; 20: 68-100.

64 Cowley MA, Smith RG, Diano S, Tschop M, Pronchuk N, Grove KL, Strasburger CJ, Bidlingmaier M, Esterman M, Heiman ML, Garcia-Segura LM, Nillni EA, Mendez P, Low MJ, Sotonyi P, Friedman JM, Liu H, Pinto S, Colmers WF, Cone RD, Horvath TL. The distribution and mechanism of action of ghrelin in the CNS demonstrates a novel hypothalamic circuit regulating energy homeostasis. Neuron 2003; 37: 649-661.

65 Abrahamson EE, Moore RY. The posterior hypothalamic area: chemoarchitecture and afferent connections. Brain Res 2001; 889: $1-22$.

66 Elmquist JK. Hypothalamic pathways underlying the endocrine, autonomic, and behavioral effects of leptin. Physiol Behav 2001; 74: 703-708.

67 Roselli-Rehfuss L, Mountjoy KG, Robbins LS, Mortrud MT, Low MJ, Tatro JB, Entwistle ML, Simerly RB, Cone RD. Identification of a receptor for gamma melanotropin and other proopiomelanocortin peptides in the hypothalamus and limbic system. Proc Natl Acad Sci USA 1993; 90: 8856-8860.

68 Mountjoy KG, Mortrud MT, Low MJ, Simerly RB, Cone RD. Localization of the melanocortin-4 receptor (MC4-R) in neuroendocrine and autonomic control circuits in the brain. Mol Endocrinol 1994; 8: 1298-1308.

69 Bittencourt JC, Presse F, Arias C, Peto C, Vaughan J, Nahon JL, Vale W, Sawchenko PE. The melanin-concentrating hormone system of the rat brain: an immuno- and hybridization histochemical characterization. J Comp Neurol 1992; 319: 218-245.

70 Rollins BL, King BM. Amygdala-lesion obesity: what is the role of the various amygdaloid nuclei? Am J Physiol Regul Integr Comp Physiol 2000; 279: R1348-R1356.

71 Magoul R, Ciofi P, Tramu G. Visualization of an efferent projection route of the hypothalamic rat arcuate nucleus through the stria terminalis after labeling with carbocyanine dye (DiI) or proopiomelanocortin-immunohistochemistry. Neurosci Lett 1994; 172: 134-138.

72 King BM, Cook JT, Rossiter KN, Rollins BL. Obesity-inducing amygdala lesions: examination of anterograde degeneration and retrograde transport. Am J Physiol Regul Integr Comp Physiol 2003; 284: R965-R982.

73 Huang XF, Han M, South T, Storlien L. Altered levels of POMC, AgRP and MC4-R mRNA expression in the hypothalamus and other parts of the limbic system of mice prone or resistant to chronic high-energy diet-induced obesity. Brain Res 2003; 992: 9-19.
74 Saito Y, Cheng M, Leslie FM, Civelli O. Expression of the melaninconcentrating hormone $(\mathrm{MCH})$ receptor mRNA in the rat brain. J Comp Neurol 2001; 435: 26-40.

75 Cavdar S, Onat F, Aker R, Sehirli U, San T, Yananli HR. The afferent connections of the posterior hypothalamic nucleus in the rat using horseradish peroxidase. J Anat 2001; 198: 463472 .

76 Kile BT, Schulman BA, Alexander WS, Nicola NA, Martin HM, Hilton DJ. The SOCS box: a tale of destruction and degradation. Trends Biochem Sci 2002; 27: 235-241.

77 Emanuelli B, Peraldi P, Filloux C, Sawka-Verhelle D, Hilton D, Van Obberghen E. SOCS-3 is an insulin-induced negative regulator of insulin signaling. J Biol Chem 2000; 275: 15985-15991.

78 Mosavi LK, Minor DL Jr, Peng ZY. Consensus-derived structural determinants of the ankyrin repeat motif. Proc Natl Acad Sci USA 2002; 99: 16029-16034.

79 Kohroki J, Fujita S, Itoh N, Yamada Y, Imai H, Yumoto N, Nakanishi T, Tanaka K. ATRA-regulated Asb-2 gene induced in differentiation of HL-60 leukemia cells. FEBS Lett 2001; 505: 223228.

80 Boengler K, Pipp F, Fernandez B, Richter A, Schaper W, Deindl E. The ankyrin repeat containing SOCS box protein 5: a novel protein associated with arteriogenesis. Biochem Biophys Res Commun 2003; 302: $17-22$.

81 McDaneld TG, Hancock DL, Moody DE. Altered mRNA abundance of ASB15 and four other genes in skeletal muscle following administration of beta-adrenergic receptor agonists. Physiol Genom 2003; 16: $275-283$.

82 Kile BT, Metcalf D, Mifsud S, DiRago L, Nicola NA, Hilton DJ, Alexander WS. Functional analysis of Asb-1 using genetic modification in mice. Mol Cell Biol 2001; 21: 6189-6197.

83 Wilcox A, Katsanakis KD, Bheda F, Pillay TS. Asb6, an adipocytespecific ankyrin and SOCS box protein, interacts with APS to enable recruitment of elongins $\mathrm{B}$ and $\mathrm{C}$ to the insulin receptor signaling complex. J Biol Chem 2004; 279: 38881-38888.

84 Mizuno Y, Sotomaru Y, Katsuzawa Y, Kono T, Meguro M, Oshimura M, Kawai J, Tomaru Y, Kiyosawa H, Nikaido I, Amanuma H, Hayashizaki Y, Okazaki Y. Asb4, Ata3, and Den are novel imprinted genes identified by high-throughput screening using RIKEN cDNA microarray. Biochem Biophys Res Commun 2002; 290: 1499-1505.

85 Kamura T, Sato S, Haque D, Liu L, Kaelin WG Jr, Conaway RC, Conaway JW. The Elongin BC complex interacts with the conserved SOCS-box motif present in members of the SOCS, ras, WD-40 repeat, and ankyrin repeat families. Genes Dev 1998; 12: 3872-3881.

86 Zhang JG, Farley A, Nicholson SE, Willson TA, Zugaro LM, Simpson RJ, Moritz RL, Cary D, Richardson R, Hausmann G, Kile BJ, Kent SB, Alexander WS, Metcalf D, Hilton DJ, Nicola NA, Baca $\mathrm{M}$. The conserved SOCS box motif in suppressors of cytokine signaling binds to elongins $\mathrm{B}$ and $\mathrm{C}$ and may couple bound proteins to proteasomal degradation. Proc Natl Acad Sci USA 1999; 96: 2071-2076.

87 Liu Y, Li J, Zhang F, Qin W, Yao G, He X, Xue P, Ge C, Wan D, $\mathrm{Gu}$ J. Molecular cloning and characterization of the human ASB-8 gene encoding a novel member of ankyrin repeat and SOCS box containing protein family. Biochem Biophys Res Commun 2003; 300: 972-979.

88 Schoenfeld AR, Davidowitz EJ, Burk RD. Elongin BC complex prevents degradation of von Hippel-Lindau tumor suppressor gene products. Proc Natl Acad Sci USA 2000; 97: 8507-8512. 